\title{
FUNGSI KONSTITUSI DALAM PEMBATASAN KEKUASAAN
}

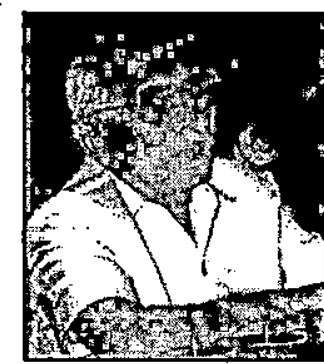

Oleh : Sri Soemantri M.' .

Selain sebagai dokumen nasional. dan tanda dari kedewasaan kemerdekaan sebagai bangsa, konstitusi adalah juga sebagai alat yang berisi sistem politik dan sistem hukum yang hendak diwujudkan, demikian yang diungkapkan oleh Sri Soemantri $M$ : Hal itu berarti bahwa konstitusi memiliki peran yang bukan saja besar, tetapi paling strategis dalam pembatasan kekuasaan.

\section{PENDAHULUAN}

Masalah yang terdapat dalam judul tulisan ini merupakan bahasan berbagai ilmu, sekurang-kurangnya hal itu dapat dibahas dalam ilmu negara (umum),ilmu politik dan ilmu hukum tata negara. Walaupun dilihat dari rumusannya merupakan kajian teoritik, akan tetapi hal itu dapat digunakan untuk menjawab pertanyaan, mengapa dalam setiap negara selalu terdapat Konstitusi? Untuk apa para pendiri negara Indonesia menetapkan Undang-Undang Dasar 1945 ? Dengan demikian ada korelasi antara negara,konstitusi dan pembatasan kekuasaan. Oleh karena itu, perlu dikaji dan dibahas, pertáma, negara, kedua, konstitusi, dan yang ketiga kekuasaan. Karena itu, pembahasan terhadap ketiga hal di atas akan menggunakan ( akan dicoba menggunakan ) baik ilmu hukum tata negara maupun ilmu politik. Ini berarti bahwa tema seminar "dalam rangka memanfaatkan momentum 30 tahun Supersemar" yang dirumuskan dengan perkataan "Hukum dan Kekuasaan" sangat tepat.

Surat Perintah 11 Maret 1966 merupakan era baru setelah terjadinya usaha perebutan kekuasaan yang gagal oleh G-30 S/PKI. Dengan surat perintah tersebut telah dilakukan berbagai keputusan politik penting, diantaranya 
ialah adanya janji untuk melaksanakan Undang-Undang Dasar 1945 secara mumi dan konsekuen. Timbul pertanyaan, mengapa janji itu dikemukakan? . Apa yang terjadi terhadap pelaksanaan Undang-Undang Dasar 1945 sebelumnya? Bagi pemerhati Hukum Tata Negara, latar belakang timbulnya janji tersebut ialah terjadinya penyimpangan terhadap pelaksanaan Undang-Undang Dasar 1945. Oleh karena itu muncul janji tersebut yang sudah barang tentu tidak ingin dan tidak akan diulang kembali. Oleh karena itulah dalam rangka memperingati Surat Perintah 11 Maret 1966 perlu dikaji ulang korelasi antara Hukum dan Kekuasaan. Dalam tulisan ini hendak dijawab masalah sebagai berikut:

1. Apabila kita pelajari negara-negara yang ada di dunia ini selalu terdapat konstitusi atau undang-undang dasar di dalamnya. Oleh karena itu timbul pertanyaan, mengapa dalam setiap negara terdapat konstitusi?

2. Untuk apa konstitusi diadakan? Apa fungsinya konstitusi?

\section{MEGARA DAN KOUSTITUSI}

Ada korelasi antara negara dan konstitusi, itulah sebabnya dalam setiap negara selalu terdapat konstitusi. Bangsa Indonesia sendiri ketika akan "mendapat" kemerdekaan dan setelah dibentuknya Badan Penyelidik Usaha-usaha Persiapan Kemerdekaan Indonesia telah pula mempersiapkan undang-undang dasar. Hal ini dibahas dalam sidang-sidang Badan Penyelidik Usaha-usaha Persiapan Kemerdekaan Indonesia (BPUPKI) dari tanggal.29 Mei 1945. sampai dengan tanggal 1 Juni 1945 dan dari tanggal 10
Juli 1945 sampai dengan 17 Juli 1945 (Lihat: Risalah Sidang Badan Penyelidik Usaha-usaha Persiapan Kemerdekaan Indonesia, Sekretariat Negara Republik Indonesia, Jakarta). Untuk menjawab korelasi antara negara dan konstitusi, periu dijawab lebih' dulu, apa negara itu? R.M. Mac Iver, sebagaimana dikutip oleh C.F. Strong (Modern Political Constitutions, 1973, 5) mengatakan:

"a state in the fundamental assosiation for the maintenance and development of social order, and to this end its central institution is endowed with the united power of the community".

Dari pendapat R.M.Mac Iver tersebut perlu dicermati anak kalimat yang berbunyi:

"and to this end its central institution is endowed with the united power of the community".

Dengan demikian, untuk pemeliharaan dan pengembangan tata tertib masyarakat, lembaga sentral (pusat) diberi (dianugerahi) kekuasaan bersama dari masyarakat.

Dari batasan di atas jelas bahwa yang menentukan keberhasilan pemeliharaan dan pengembangan tata tertib tersebut adalah kekuasaan yang berada di lembaga sentral. Dalam pada itu seorang. pakar: hukum tata negara Belanda J.H.A. Logemann berpendapat bahwa negara adalah organisasi kekuasaan (matchs organisatie). Mengapa J. H. A. Logemann berpendapat demikian? Karena, dalam setiap negara akan selalu terdapat adanya pusat-pusat kekuasằan, baik yang terdapat dalam supra struktur. politik maupun yang 
terdapat dalam infra struktur politik (H.R. Sri Soemantri M, jurnal ilmiah Untag Jakarta, No.1, Januari 1945). Pusat-pusat kekuasaan tersebut jelas mempunyai kekuasaan, artinya mempunyai kemampuan mengendalikan pihak lain. Dalam pada itu, seperti diketahui, bagaimana pun kecilnya, setiap kekuasaan cenderung disalahgunakan yang memegangnya. (Sri Soemantri Martosoewignyo, Pidato Pengukuhan Guru Besar di Universitas Padjadjaran, 1987). Adanya kecenderungan . penyalahgunaan kekuasaan tersebut memaksa mereka yang terlibat dalam usaha berdirinya negara mencari jalan keluar, dengan cara bagaimana penyalahgunaan kekuasaan tersebut sekurang-kurangnya dapat dibatasi dan dicegah.

Para pendiri Negara Kesatuan Republik Indonesia sepakat bahwa untuk mencegah terjadinya penyalahgunaan kekuasaan harus diadakan undang-undang dasar atau konstitusi. Undang-undang dasar atau konstitusi sebagai bagian dari hukum dasar harus diciptakan untuk mencegah terjadinya penyalahgunaan kekuasaan.

\section{ARII DAN MAKHA KONSTITUSI}

Istilah konstitusi berasal dari bahasa Inggris "Constitution" dan bahasa Perancis "Constitution", dengan ucapan berbeda. Istilah undang-undang dasar itu sendiri berasal dari perkataan Belanda "grondwet" (grond berarti dasar dan wet berarti undangundang). Dilihat dari penggunaan perkataan tersebut, sebenarnya tidak ada perbedaan antara istilah konstitusi dan undang-undang dasar. Keduanya mengacu pada pengertian yang sama. Dengan demikian, apabila konstitusi mempunyai pengertian luas dan sempit, hal itu juga berlaku terhadap "grondwet" (lihat Winkler
Prins Encyclopaedia). Yang menjadi pertanyaan ialah, apa yang dimaksud dengan konstitusi? Ada beberapa pendapat tentang batasan atau perumusan konstitusi, mulai dari yang abstrak dan singkat sampai dengan yang kọnkrit dan panjang. Berkenaan dengan hal itu saya akan mengemukakan pendapat CF.Strong (1973:10) seperti berikut:

“........ a constitution may be said to be a collection of principles according to which the powers of the goverment, the rights of the governed, and the relations between the two are adjusted".

Apabila kita ikuti pakar ilmu politik Inggris tersebut, konstitusi sebagai kumpulan asas-asas mengatur tiga materimuatan pokok, yaitu:

1. kekuasaan pemerintah (dalam arti luas);

2. hak-hak yang diperintah (maksudnya hak-hak asasi); dan

3. hubungan antara yang memerintah dan yang diperintah.

Dalam pada itu J.G. Steenbeek dalam pidato pengukuhannya sebagai gurubesar dalam mata kuliah Hukum Tata Negara dan Hukum Administrasi, yang diberi judul De Beproefde Grondwet mengatakan bahwa ada tiga macam ciri yang harus dipenuhi suatu konstitusi yang benar (de ware constitutie), yaitu:

1. Adanya jaminan terhadap hak-hak asasi manusia dan warga negara;

2. Ditetapkannya susunan ketatanegaraan suatu negara yang bersifat fundamental;

3. Adanya pembagian dan pembatasan tugas-tugas ketatanegaraan yang juga 
bersifat fundamental. (dikutip dari Sri Soemantri, 1986, hal 51).

Apabila pendapat kedua pakar di atas kita perbandingkan, secara umum dapat dikatakan bahwa antara keduanya tidak ada perbedaan yang mendasar. Dan apabila perumusan konstitusi, baik dari pakar ilmu politik Inggris dan pakar ilmu hukum tata negara Belanda kita kaji, apa yang dikemukakan pada hakekatnya mengatur pembatasan kekuasaan dalam negara. Seperti kita ketahui, pembatasan kekuasaan yang tercantum dalam konstitusi menyangkut dua hal, pertama pembatasan kekuasaan yang berkenaan dengan isinya dan kedua pembatasan kekuasaan yang berkenaan dengan waktu. Pembatasan kekuasaan tentang isi berkaitan dengan tugas, wewenang serta berbagai macam hak yang diberikan kepada masing-masing lembaga, sedangkan pembatasan $\cdot k e k u a s a a n$ yang berkenaan dengan waktu berkenaan dengan masa jabatan yang diberikan kepada pejabat yang memegang jabatan serta berapa kali seorang pejabat dapat dipilih kembali.

\section{MAKNA KOHSTITUSI DAY MATERI MUATANHYA.}

Bahwa setiap negara mempunyai konstitusi tidak dapat dipisahkan. dari kenyataan untuk apa konstitusi diadakan. Dalam pada itu bila kita kaji konstitusikonstitusi yang dipunyai oleh negaranegara di dunia ternyata terdapat konstitusi-konstitusi yang terdiri dari banyak pasal dan mengatur banyak hal. Di samping itu ada pula konstitusikonstitusi yang hanya terdiri dari beberapa pasal dan oleh karena itu, yang diatur hanyalah hal-hal yang bersifat pokok saja.
Karena negara adalah sebuah organisasi, dalam setiap konstitusi akan diatur segala sesuatu yang berkenaan dengan organisasi tersebut. Walaupun demikian, masing-masing negara (bangsa) berbeda pendapat tentang apa yang harus diatur dalam konstitusi.

Henc van Maarseveen dan Ger van der Tang dalam sebuah studinya terhadap konstitusi-konstitusi di dunia dan yang dituangkan dalam buku dengan judul "Written Constitution" antara lain mengatakan bahwa:

1. "Constitution as a means of forming the state's own political and legal system";

2. "Constitution as a national document" dan "as a birth certificate" dan bahkan "as a sign of adulthood and independence".

Seperti kita ketahui, konstitusi atau undang-undang dasar adalah sumber utama hukum tatanegara suatu negara:Sebagai suatu sumber hukum tatanegara yang paling penting, setiap konstitusi selalu mempunyai corak (warna) nasional. Itulah sebábnya kedua orang pakar. hukum tata negara Belanda di atas mengatakan, bahwa selain sebagai dokumen nasional, konstitusi adalah juga alat untuk membentuk sistem politik dan sistem hukum negaranya sendiri. Itulah sebabnya undang-undang dasar (grondwet) sebagai konstitusi tertulis merupakan sebuah dokumen formal yang berisi:

1. Hasil perjuangan politik bangsa di waktu yang lampau; 
2. Tingkat-tingkat tertinggi perkembangan ketatanegaraan bangsa;

3. Pandangan tokoh-tokoh bangsa yang hendak diwujudkan baik untuk waktu sekarang maupun untuk masa yang akan datang;

4. Suatu keinginan, dengan mana perkembangan kehidupan ketatanegaraan bangsa hendak dipimpin. (Sri Soemantri M, 1986, hal 2).

Itulah sebabnya, setiap negara mempunyai konstitusi yang isinya berbeda'satu sama lain.Walaupun demikian, apabila kita perhatikan semua konstitusi, ternyata setiap konstitusi telah mengatur tiga kelompok materi muatan (lihat bagian sebelumnya tentang "de ware constitutie").

Apabila masing-masing materi-muatan tersebut kita kaji, maka kita dapat menarik kesimpulan bahwa di samping sebagai:

1. Dokumen nasional dan tanda kedewasaan dari kemerdekaan sebagai bangsa, konstitusi adalah juga sebagai

2. Alat yang berisi sistem politik dan sistem hukum yang hendak diwujudkan.

\section{PENGalaman SEJARAK}

Seperti ternyata dari sejarah ketatanegaraan bangsa, rancangan undang-undang dasar dipersiapkan oleh wakil-wakil bangsa Indonesia yang duduk dalam suatu Badan Penyelidik. Usahausaha Persiapan Kemerdekaan Indonesia (BPUPKI). Walaupun BPUPKI dibentuk oleh Pemerintah Balatentara Jepang, pada umumnya para anggotanya mempunyai kebebasan mengemukakan
pandangan-pandangannya.Hal ini dapat kita lihat dari pandangan umum yang disampaikan pada sidang Pertama, yaitu antara tanggal 29 Mei 1945 sampai dengan tanggal 1 Juni 1945. Panitia Kecil yang terdiri dari 9 (sembilan) orang telah berhasil menginventarisasi 9 (sembilän) masalah pokok:

1. Permintaan Indonesia merdeka selekas-lekasnya;

2. Tentang dasar negara;

3. masalah unifikasi dan federasi;

4. Bentuk pemerintahan dan Kepala Negara;

5. Tentang kewarganegaraan; :

6. Masalah pemerintahan di daerah;

7. Masalah agama dan hubungannya dengan negara;

8. Masalah pembelaan (tanah air); dan

9. Masalah keuangan. (Sri Soemantri, 1986, hal 27).

Seperti kita ketahui BPUPKI mengadakan dua kali sidang. Sidang yang kedua berakhir pada tanggal 17 Juli 1945. Undang-undang dasar yang telah berhasil disusun diserahkan kepada pemerintah yang akan memberikan kemerdekaan kepada bangsa Indonesia. "Hadiah Kemerdekaan" tersebut tidak terwujud, oleh karena pada tanggal 14 Agustus1945 Jepang telah menyerah tanpa syarat kepada pihak sekutu: Kejadian-kejadian itulah yang menjadi alasan bangsa Indonesia melalui dua orang wakilnya, yaitu Ir. Soekarno dan Drs. Moh. Hatta memproklamasikan kemerdekaannya: Ada hal yang menarik dalam sálah satu sidang BPUPKI pada tanggal 15 Juli 1945. Dalam sidang tersebut Moh. Hatta 
antara lain mengatakan sebagai berikut:

"Kita mendirikan negara baru di atas dasar gotong-royong dan hasil usaha bersama. Tetapi satu hal yang saya kuatirkan, kalau tidak ada satu keyakinan atau satu pertanggungan kepada rakyat dalam undang-undang dasar yang mengenai hal untuk mengeluarkan suara, yaitu bahwa nanti di atas undang-unadang dasar yang kita susun sekarang ini, mungkin terjadi sùatu bentukan negara yang tidak kita setujui... Hendaklah kita memperhatikan syarat-syarat supaya negara yang kita bikin, jangan menjadi Negara Kekuasaan. Kita menghendaki negara pengurus, kita membangun masyarakat baru yang berdasar kepada gotong-royong, usaha bersama, tujuan kita ialah membaharui masyarakat. Tetapi di sebelah itu janganlah kita memberikan kekuasaan yang tidak terbatas kepada negara untuk menjadikan di atas negara itu suatu negara. kekuasaan." (Risalah Sidang BPUPKI, Setneg RI, 1992, hal 209).

Dari kutipan tersebut jelas bahwa Bung Hatta sebagai salah seorang tokoh pergerakan nasional menghendaki agar dalam undang-undang dasar yang hendak dibentuk dicantumkan pasal-pasal yang memberikan kepada: warga negara hak untuk mengeluarkan pendapat dan lain- lain. Setelah melalui perdebatan, pada akhirnya dalam UUD 1945 terdapat pengaturan hak-hak asasi yang tercantum dalam Pasal-pasal 27, 28, 29 ayat (2), 30 ayat (1), dan 34 .

Seperti kita ketahui, UUD 1945 terdiri dari Pembukaan, Batang Tubuh yang terdiri dari 37 pasal, Aturan Peralihan, Aturan Tambahan dan Penjelasan tentang Undang-Undang Dasar Negara Indonesia.UUD 1945 telah berlaku dalam dua kurun waktu, yaitu :

1. 18 Agustus 1945 sampai 27 Desember 1949; dan

2. 5 Juli 1959 sampai sekarang. Dalam pada itu antara 27 Desember 1949 sampai 17 Agustus 1950 telah berlaku Konstitusi Republik Indonesia Serikat (RIS). Konstitusi RIS ini terdiri dari Mukadimah, 197 pasal serta lampiran yang berisi wewenang yang diberikan kepada Pemerintah Federal RIS. Antara 17 Agustus 1950 sampai 5 Juli 1959 telah berlaku Undang-Undang Dasar Sementara 1950. UUD Sementara 1950 terdiri dari Mukadimah dan 146 pasal.

Apabila Konstitusi RIS 1949, UUD Sementara 1950 dan UUD 1945 kita kaji, ternyata di dalamnya juga ditemukan 3 kelompok materi-muatan seperti kita jumpai pada konstitusi-konstitusi pada

*) Prof. Dr. H. Sri Soemantri M., SH. adalah dosen UNPAD Bandung, serta Guru Besar Luar Biasa di FH. Ull Yogyakarta 